\title{
O DISSECADOR DE PASSARINHOS E A IDADE DA RAZÃo \\ - REFLEXÕES SOBRE A RELAÇÃO ENTRE RECEPÇÃO E CRIAÇÃO NA PRODUÇÃO LITERÁRIA
}

por Kleber Pereira dos Santos ${ }^{1}$

\section{RESUMO}

Partindo de estudo anterior sobre a importância do intertexto sartriano durante a escrita e reescrita do romance $O$ Ventre, de Carlos Heitor Cony, este artigo propõe-se refletir sobre a relação entre recepção e criação na produção literária.

PALAVRAS-CHAVE: Carlos Heitor Cony, Existencialismo, Jean-Paul Sartre, Crítica Genética, Estética da Recepção, Literatura Comparada.

\section{ABSTRACT}

From a previous study on the importance of sartrean intertext during the writing and rewriting of the novel $O$ Ventre of Carlos Heitor Cony, this article intends to reflect on the relationship between creation and reception in the literature.

KEYWORDS: Carlos Heitor Cony, Existentialism, Jean-Paul Sartre, Genetic Criticism, Reception Aesthetics, Compared Literature.

\section{Introdução}

\begin{abstract}
La citation tente de reproduire dans l'écriture une passion de lecture, de retrouver l'instantanée fulgurance de la sollicitation, car c'est bien la lecture, solliciteuse et excitante, qui produit la citation. La citation répète, elle fait retentir la lecture dans l'écriture: c'est qu'en vérité lecture et écriture ne sont qu'une seule et même, la pratique du texte qui est pratique du papier. (COMPAGNON, 1979, p. 27)
\end{abstract}

Iniciar um artigo de crítica literária com semelhante citação, tendo em vista o intenso uso do procedimento nesse gênero textual, pode até parecer uma mera estratégia justificativa, um modo de se desculpar pelo aparente excesso na utilização do recurso, apoiando-se no argumento de autoridade que é mencionar um trecho das reflexões de um notório especialista no assunto. Contudo, não é esse o real motivo do extrato do texto de Compagnon estar aqui presente. A atividade crítica estabelece, inevitavelmente, uma relação parasitária com os inúmeros textos com os quais dialoga ${ }^{2}$, uma relação infinita, pois, o texto que cita hoje, que se alimenta de outro(s), pode ser futuro pasto para novos rebanhos de leitores/escritores a surgir. Nada de novo no front; mais do que mera característica - por vezes vista como pernóstica - do discurso crítico, tal "antropofagia"

\footnotetext{
${ }^{1}$ Mestre em Teoria Literária e Literatura Comparada pela Faculdade de Filosofia, Letras e Ciências Humanas da Universidade de São Paulo.

2 "Será que uma citação é um parasita estranho no corpo do texto principal, ou o texto interpretativo é que constitui o parasita ao enlaçar e estrangular a citação que lhe serve de hospedeira" (MILLER, 1995, p. 12). Em consonância com tal observação, Leyla Perrone-Moisés afirma que "a crítica não é nem literatura, nem nãoliteratura; é uma espécie de paraliteratura, quase diríamos uma pária-literatura." (PERRONE-MOISÉS, 1978, p. 66).
} 
textual é elemento fundamental na própria relação estabelecida entre os textos literários, não apenas na pós-modernidade, período no qual esse aspecto reiterativo veio ao primeiro plano da produção artística e do discurso crítico sobre a mesma, mas desde sempre. Não por acaso, Montaigne, em pleno século XVI, já considerava que "nous ne faison que nous entregloser" (MONTAIGNE apud HUTCHEON, 1991, p. 163).

O que justifica a presença do comentário de Compagnon sobre a importância da citação é o fato de que neste artigo se abordará o final do romance $O$ Ventre, de Carlos Heitor Cony e sua íntima relação com o final do romance L'âge de raison, de Jean-Paul Sartre. Menos do que um modo falacioso e desnecessário de "provar" a existência do diálogo da obra em pauta com a ficção sartriana, algo que pode ser devidamente exposto e problematizado sem recorrer a tal expediente, o que se buscará é despertar reflexões gerais sobre a interpenetração das atividades - algumas vezes consideradas como pertencentes a pólos opostos, vistas como posições estanques, fixas e inconciliáveis - de leitura e escrita, de recepção e produção, que ocorre no seio do processo criativo. Tendo como ponto de partida as reflexões suscitadas pela análise genética do processo de criação do romance $O$ Ventre e pela percepção da importância de ter em mente o intertexto existencial, especialmente a leitura dos romances sartrianos empreendida por Cony, para compreender algumas das facetas da prática de escrita e reescrita das distintas versões da obra ${ }^{3}$, neste artigo se pretende esboçar uma compreensão teórica de tal simbiose que, com certeza, não deve ser válida apenas para descrever o trabalho escritural de Carlos Heitor Cony.

\section{I - Dois Finais Desenganados - Um exemplo de intertextualidade explícita em $O$ Ventre}

Diversos foram os aspectos abordados na análise das versões de $O$ Ventre que remetem ao diálogo intertextual entre a obra e os romances existencialistas, especificamente, a produção ficcional sartriana. No entanto, é salutar observar que nesse primeiro romance do autor carioca, assim como em sua produção literária posterior, não há - aparentemente - nenhuma referência explícita ao filósofo francês Jean-Paul Sartre, nenhuma frase imediatamente identificável como oriunda de textos sartrianos, nenhum comentário sobre livros do autor ou sobre personagens suas. Inclusive em Pessach: $a$ travessia, obra publicada em 1967, ao descrever o estilo dos romances escritos pelo quase autobiográfico protagonista Paulo Simões, o nome que surge é o de Henry Miller, autor com traços da atmosfera existencial parisiense cravados em sua escrita, mas não o principal representante da narrativa desenvolvida nesse ambiente. Há, como o próprio escritor carioca ressalta, até "cacos" de Sartre na escrita de $O$ Ventre, mas todos estão imiscuídos na voz narrativa, e não surgem como a voz de um outro. Ao investigador tal presença constante, mas diluída, torna a tradicional busca da "prova" da contaminação da água pura da expressão individual pelo elemento alienígena invasor - para usar imagens que reproduzem a ainda bastante comum concepção negativa do intercâmbio textual, visão que

\footnotetext{
${ }^{3}$ Aspectos abordados no primeiro capítulo da dissertação de mestrado de minha autoria Da Paixão Inútil: $O$ existencialismo na escrita de Carlos Heitor Cony, defendida em fevereiro de 2009 como parte da obtenção do título de mestre em Teoria Literária e Literatura Comparada pela FFLCH/USP. Na primeira parte desse estudo são comparadas quatro versões distintas do romance $O$ Ventre (três edições publicadas, respectivamente, em 1958, 1987 e 1998 e um datiloscrito escrito em 1955). A análise das diferenças encontradas na passagem de uma versão para a outra é, nesse estudo, relacionada com o diálogo com o intertexto existencial essencial na concepção da primeira versão da obra e reiterado ao longo dos processos de reescrita pelo qual passou.
} 
o identifica com a idéia de plágio, cópia, falta de criatividade, etc. - uma tarefa complicada, mas bastante instigante. Uma citação, um nome de personagem reutilizado, talvez mesmo da obra com a qual se está mantendo contato, sempre deixa a mistura facilmente visível, como óleo na água. Em $O$ Ventre não há pistas tão óbvias assim, apesar do tom do romance ser claramente existencialista como já era destacado por críticos na época de seu lançamento há 51 anos.

Uns dos momentos em que a presença das leituras dos romances sartrianos surge de modo mais evidente no corpo do texto de Cony são os momentos de náusea de José Severo durante uma de suas viagens como motorista de ônibus pelas ruas de Maceió. Invadido pela total falta de sentido de sua existência, Severo se desliga da função que está exercendo, passa a destratar os passageiros, começa a passar mal, até abandonar o ônibus sob protestos e xingamentos ${ }^{4}$. A experiência da náusea é vinculada tradicionalmente à cena em que Roquentin tem uma "iluminação" diante de uma raiz de árvore em La nausée $e^{5}$, contudo, tal momento reaparece também em outros escritos de Jean-Paul Sartre. A náusea, instante em que é desvelada ao sujeito sua contingência, em que a segurança dos alicerces de sua vida (necessidade, destino, futuro, passado, personalidade, leis, tradições, crenças etc.) é ao menos temporariamente - suprimida e o indivíduo fica sem chão firme, assustado com sua própria liberdade, é uma das maiores marcas da ficção sartriana e, inclusive, de obras de outros autores que mantiveram relações de afinidade com a corrente existencial, cada qual com sua especificidade. De Camus e Beauvoir, ainda no contexto francês, passando pela ficção filosófica de Vergílio Ferreira em Portugal, indo às Américas nas experiências lisérgicas da geração Beat norte-americana ou no existencial túnel do argentino Ernesto Sábato, ao ponto de - segundo Benedito Nunes - visitar, nem que só por semelhança, os momentos de epifania que povoam toda a obra de Clarice Lispector, a náusea, esse momento catártico de desconforto existencial, é um dos traços mais característicos de obras que dialogam com o pensamento existencialista, apesar de não ter sua origem nele, nem reduzir-se a ele, o que pode pôr em "dúvida" sua capacidade para significar uma real referência à ficção existencial ao surgir no romance do escritor carioca.

Contudo, pode-se encontrar um vestígio da relação intencional de Cony com a narrativa sartriana, particularmente com um romance específico do filósofo francês restringindo bem o foco para assim atender ao apelo de "objetividade" de parte dos estudos comparativistas -, ao se comparar os finais dos romances $O$ Ventre e L'âge de raison. Tal parentesco foi destacado pelo próprio Carlos Heitor Cony durante o primeiro encontro com o escritor para conversar sobre esta pesquisa, ocorrido em 08 de dezembro de 2004. No capítulo final de $O$ Ventre, logo após a constatação fria do suicídio do irmão (matemático brilhante, filho exemplar, casado com Helena, mulher que Severo desejou desde a infância)

\footnotetext{
4 "Súbito, um calor subiu pelo rosto. Logo senti vontade de vomitar, a boca amargava, a testa encharcada de suor. Sabia o que era. Encostei o ônibus na calçada. Deixei o volante e encarei os passageiros como se não soubesse o que eles faziam em torno de $\operatorname{mim}($...) Eu estava livre. E quando se está livre pode-se fazer tudo, inclusive voltar para as grades." (CONY, 1998, p. 99). As grades, no caso, é o retorno ao seu passado. Logo após, volta para o Rio para assistir a agonia do pai, figura ameaçadora em sua existência de filho maldito, ovelha negra, bastardo.

5 "La racine du marronnier s'enfonçait dans la terre, juste au-dessous de mon blanc. Je ne me rappelais plus que c'était une racine. Les mots s'étaient évanouis et, avec eux, la signification des choses, leurs modes d'emploi, les faibles repères que les hommes ont tracés à leur surface. J'étais assis, un peu voûté, la tête basse, seul en face de cette masse noire et noueuse, entièrement brute et qui me faisait peur. Et puis j'ai eu cette illumination." (SARTRE, 1938, p. 181).
} 
e um breve sumário narrativo dos acontecimentos subsequentes, o narrador, ao comentar com irônica benevolência a sádica curiosidade do filho herdado ${ }^{6}$, sua bestial ação de destripar os canários para tirar a "prova dos nove" sobre a declaração do pai adotivo a respeito da origem do som produzido pelo animal - Severo impaciente com a pergunta tinha dito que os pássaros possuíam um apito na barriga -, pronuncia uma oração que estruturalmente remete imediatamente à mesma construção duplicada, repetida, da afirmação que encerra o romance L'âge de raison, de Jean-Paul Sartre, como se pode observar abaixo:

Helena não foi ao entêrro. Recebeu a notícia com calma.

- Era uma das coisa que êle podia fazer - disse.

Três anos depois Helena juntou-se a um visionário que foi explorar borracha na Amazônia. Morreram por lá mesmo, vítimas de uma febre misteriosa. Ela me deixou um bilhete e o filho para tomar conta.

O garoto é odioso. Eu trato bem dele para me distrair e me purificar. Outro dia êle quiz (sic) uns canários que vimos na rua da Assembléia. Chorou, queria os canários, fez malcriação em plena rua.

Comprei-lhe os canários.

Os canários cantavam o dia inteiro. "Por que êles cantam?" - perguntoume. "Êles têm um apito dentro da barriga" - expliquei.

Ontem, quando cheguei em casa, os canários estavam mortos, com as tripas para fora. Procurei o guri. Êle ouviu a minha espinafração com o mesmo olhar de troça que Helena fazia: era meio estrábico nesses momentos. PergunteiIhe por que havia feito aquilo.

- Eu queria ver o apito que êles têm nas tripas!

Levei-o ao cinema depois. Indubitàvelmente, êsse menino promete, não há dúvidas, êsse menino promete... (CONY, 1955, p. 260-261). ${ }^{7}$

Mathieu vit disparaître Daniel et pensa: "Je reste seul." Seul, mais plus libre qu'auparavant. II s'était dit, la veille: "Si seulement Marcelle n'existait pas." Mais c'était un mensonge. "Personne n'a entravé ma liberté, c'est ma vie qui l'a bue." II referma la fenêtre et rentra dans la chambre. L'odeur d'Ivich y flottait encore. II respira l'odeur et revit cette journée de tumulte. II pensa: "Beaucoup de bruit pour rien." Pour rien: cette vie lui était donnée pour rien, il n'était rien et cependant il ne changerait plus: il était fait. Il ôta ses chaussures et resta immobile, assis sur le bras du fauteuil, un soulier à la main; il avait encore, au fond de la gorge, la chaleur sucrée du rhum. Il bâilla: il avait fini sa journée, il en avait fini avec sa jeunesse. Déjà des morales éprouvées lui proposaient discrètement leurs services: il y avait l'épicurisme désabusé, l'indulgence souriante, la résignation, l'esprit de sérieux, le stoïcisme, tout ce qui permet de déguster minute par minute, en connaisseur, une vie ratée. Il ôta son veston, il se mit à dénouer sa cravate. Il se répétait en bâillant: "C'est vrai, c'est tout de même vrai: j'ai l'âge de raison." (SARTRE, 1945, p. 518).

O trecho da obra retomado por Cony é a última frase do romance de Sartre. Tal referência se dá por meio de uma sutil semelhança estrutural na sentença de encerramento,

\footnotetext{
${ }^{6}$ Helena, durante uma viagem de estudo do marido à Europa, fica sob os cuidados de José Severo. Nesse período, ela engravida. No entanto, apesar do desejo de Severo, o filho não é dele. Seus momentos de quase romance com Helena ocorrem após a gravidez, num refúgio utilizado para ocultar a gravidez indevida dos olhos da sociedade carioca.

${ }^{7}$ Trecho do datiloscrito inédito, primeira versão do romance escrita em 1955 e gentilmente cedida para a realização desta pesquisa.
} 
ambas postas como fala solitária dos protagonistas, pensamento em voz alta, com elementos repetidos que passam a sensação de uma constatação lamentada. Tal semelhança fica ainda mais patente se observado o modo habitual de se traduzir para o português a entediada reflexão final de Mathieu: "Não tem dúvida, não tem dúvida, estou na idade da razão" (SARTRE, 1981, p. 365).

L'âge de raison é o primeiro tomo de um ambicioso projeto romanesco sartriano, inacabado, chamado Les chemins de la liberté. Representa um dos momentos mais férteis da produção sartriana. No ano de sua publicação, 1945, ainda no calor dos últimos acontecimentos da tragédia que se abateu sobre a Europa, tanto a sua produção filosófica como literária, ambas represadas pela situação histórica, ganham liberdade e tomam de assalto a França e, posteriormente, todo o Velho Continente e o mundo, num inaudito e inesperado vento de frescor intelectual numa terra devastada pela barbárie da guerra, apesar do tom aparentemente pessimista do pensamento existencial. Nesse romance, Mathieu Delorme, enredado com ventres, equivocados ou não, empreende uma longa e indecisa jornada por Paris para obter o dinheiro necessário para pagar o aborto do filho que engendrou em sua amante Marcelle. A cena final transcrita acima ocorre após longo diálogo entre ele e Daniel, no qual fica sabendo que este seu amigo homossexual, apenas por um desafio a si mesmo - engajar sua liberdade (de certa forma, tentativa de livrar-se dela) em algum ato irremediável, mesmo que oposto à sua vontade -, irá desposar Marcelle e assumir o filho que ela carrega no ventre. Mathieu, filósofo na altura dos 34 anos de idade, reflete sobre sua vida, sobre a perda das ilusões, sobre a impossibilidade de manter seu ingênuo projeto de estar em eterna disponibilidade ${ }^{8}$. Se podemos comparar no plano do enredo a atitude de José Severo ${ }^{9}$ em $O$ Ventre ao aceitar o "resto", tal como nomeia o filho de Helena, com a atitude de Daniel, ambos possuidores de uma indiferença em relação às alternativas da existência, incomodados com o peso da própria liberdade, no plano formal, a última frase de L'âge de raison, com sua repetição cheia de descrença na aventura humana, aceitação da inevitabilidade da inautenticidade, foi retomada na voz de José Severo ao comentar a ação do menino, o ato de destripar os pássaros, ato desmascarador da ilusão e da fantasia. Ao dizer que o "menino promete", ou seja, promete ser um indivíduo tão marcado pela rejeição, traumatizado, revoltado como o protagonista-narrador, fazendo girar novamente a roda das vítimas dos "ventres equivocados", Severo faz uma afirmação típica de um sujeito dividido entre essa revolta que vê despontar na futura geração, revolta que já foi a sua um dia, e um olhar cínico, olhar de um sujeito adaptado, que prefere aceitar seu fardo como forma de se "distrair e purificar" (CONY, 1998, p. 196). Revolta e acomodação, destroçar pássaros em busca da verdade, utilizar toda a potencialidade da negatividade ativa aceitando o sofrimento inerente de tal postura existencial ou aceitar as mentiras dos homens na idade da razão, com mais de 30 anos e com 32 dentes, suas fórmulas feitas para dar sentido e paz a uma vida malograda? Nesse diálogo intertextual explícito entre os finais dos romances em pauta, toda a tensão insolúvel - impasse não resolvido nas duas obras -

\footnotetext{
${ }^{8} \mathrm{O}$ protagonista passa todo romance resistindo a ser amarrado pelo peso de alguma decisão, seja ela o aborto, assumir o filho ou abandonar Marcelle. Mathieu deseja viver "numa espécie de permanente sursis" (SILVA, 2004, p. 133).

${ }^{9}$ Salutar notar que a imensa maioria dos protagonistas de Cony, que normalmente acumulam a função total ou parcial de narrar suas próprias histórias, vivem a crise da entrada na faixa etária da idade da razão, momento que exige definições, mesmo que ilusórias: "O protagonista típico da obra de Cony é um homem de classe média que sente o peso da entrada na 'idade da razão' sem ter conseguido a desejada segurança econômica, sem ter alcançado satisfação nos aspectos emocionais" (BUENO, 2002, p. 48).
}

$$
\sim 70 \sim
$$


entre a liberdade insuportável de uma existência consciente de sua contingência e a má-fé tranquilizadora e segura da vida cotidiana burguesa ${ }^{10}$ surge integralmente.

\section{II - A generosidade entre irmãos inimigos}

Assim como a citação de Compagnon não foi motivada pelo grande número de citações que normalmente povoam textos críticos como este, o título deste tópico não deve ser entendido como uma referência à disputa entre José Severo e seu irmão matemático presente no romance $O$ Ventre. Na verdade, trata-se da união de duas imagens utilizadas por diferentes pensadores durante suas reflexões sobre a relação entre produção e recepção na prática literária, encontradas em estudos que serão futuramente mencionados, afinal, o objetivo deste tópico será refletir sobre a falsa dicotomia que contrasta como aspectos distintos e até opostos nos atos de leitura e de escrita. Essa polaridade criticada mesmo por estudiosos especializados numa ou noutra das pontas do sistema literário, mas ainda comum ao se caracterizar as posturas de aparente atividade ou passividade na experiência estética, é recorrentemente desmentida pelos estudos dedicados às práticas de escrita dos mais diversos autores. Quando dois extremos de uma linha que deveria ser reta teimam em se atrair é, talvez, porque não se trata de uma reta e sim de um círculo. As reflexões a seguir versarão sobre a circularidade da atividade literária, a dinâmica e intensa troca de papéis existente quando um sujeito se depara com uma folha escrita ou em branco.

A distinção extremada entre as posturas subjetivas adotadas durante os atos de escrita ou de leitura possui raízes numa visão idealizada da literatura construída, basicamente, no final do século XVIII, consolidando-se na primeira metade do século XIX, auge do romantismo. Essa visão concebe o leitor como pura passividade, um recipiente vazio pronto para ser preenchido pelo saber e pelo prazer oriundo da obra que está em suas mãos. O caro leitor, por vezes ironizado nas diatribes dos grandes romancistas do período áureo do gênero, na época em que o mesmo tinha uma abrangência semelhante à alcançada hoje pelo cinema ou pela televisão, era encarado como uma página em branco ou, para modernizar a imagem, era visto como um aparelho de DVD: o livro seria o disco DVD, os olhos do consumidor o leitor óptico digital e seu cérebro a tela da televisão. A única atividade esperada dele seria "dar o play", ou seja, adquirir o livro, abri-lo e virar as páginas. Por outro lado, o escritor era imaginado e respeitado como um Deus, o ser capaz de num fiat lux criar um universo partindo do nada. Prestando contas apenas à sua vontade, sua escrita independeria de qualquer outro fator. Criação pura, independente do contexto histórico em que está sendo desenvolvida, da tradição literária que a precedeu, do ambiente literário do momento em que está sendo efetuada, do sistema de produção e comercialização das obras literárias vigente, da expectativa de leitura dos leitores comuns e dos especializados (crítica), às vezes até livre dos condicionantes da própria existência do eu produtor e, no extremo de

\footnotetext{
${ }^{10}$ Observe-se que não existem apenas essas duas alternativas. Sartre, especialmente nas obras literárias, não fecha a questão numa defesa cerrada da manutenção da disponibilidade (tanto que suas principais personagens sofrem do vazio de tal conduta), nem repudia toda e qualquer forma de engajamento, de projeção da liberdade num projeto futuro. A tensão entre a inutilidade de uma posição ou o perigo de aprisionamento apresentado pela outra perpassa todas obras ficcionais sartrianas, inclusive as peças teatrais.
} 
tal visão de absoluta autonomia, livre dos limites impostos pela própria língua que está sendo utilizada. $\mathrm{O}$ ato de escrita é visto como atividade plena e o genial escritor como o ser que é capaz de se erguer puxando os próprios cabelos.

$\mathrm{Na}$ exigência dos estudos de literatura comparada, principalmente nos estudos ainda marcados pela ideologia da tradicional escola francesa que dominou a disciplina na primeira metade do século XX, de ser comprovada em algum ponto do texto "influenciado", a presença explícita da "fonte" enxerga-se além da ilusão de objetividade científica herdada das origens filológicas da disciplina, um respeito pela noção superdimensionada de originalidade, uma confusão entre a noção de dependência e a de relação, como se a menção ao eco de outros textos num determinado escrito fosse grave acusação contra sua integridade, atentasse contra sua honra ao desmascarar sua imagem de objeto autossuficiente, por isso necessitasse de provas contundentes do "crime" para apresentar ao júri, desconsiderando que é praticamente impossível existir um ato de fala ou escrita que não retome de algum modo um enunciado anterior: "Fora da intertextualidade, a obra literária seria muito simplesmente incompreensível, tal como a palavra duma língua ainda desconhecida." (JENNY, 1979, p. 5).

Mas, mesmo considerando a naturalidade e a inevitabilidade das trocas culturais no fazer artístico, a discussão sobre a questão quando surge no estudo de um caso concreto costuma filtrar - e para isso a tal "prova" é tomada por essencial - os elementos herdados que são, por assim dizer, aparentemente "independentes" da vontade do criador, por exemplo, as formas fixas poéticas, a tradição de um gênero, a tipologia de um personagem etc. - estruturas existentes em obras anteriores, mas não diretamente dependentes ou apenas presentes nelas - e os elementos específicos intencionalmente buscados pelo criador B na obra antecedente de um criador A. Essa noção de que "a validade das comparações literárias dependia da existência de um contato real e comprovado entre autores e obras ou entre autores e países" (CARVALHAL, 1992, p. 13), visão que enfatiza a relação entre sujeitos, anterior ao esfacelamento do mesmo no discurso crítico da modernidade, subsiste mesmo num ousado e complexo estudo sobre a influência como o elaborado por Harold Bloom em $A$ angústia da influência. Afinal, sua leitura, com alto teor biografista e psicologizante, analisa a relação entre os poetas ingleses selecionados como se fosse uma luta de egos, na qual cada indivíduo utiliza diferentes estratégias, para ver quem mantém sua individuação diante das forças provenientes do olhar do outro, no caso representado pelo peso da tradição dos "poetas fortes". Por outro lado, escapando de tal postura que valoriza excessivamente a intenção subjetiva no processo de criação das obras literárias que praticamente ousa colocar o autor num imaginário divã, mas recaindo numa alta abstração, numa "despersonalização do processo criador" (NITRINI, 1997, p. 157), surge na década de 1970 o conceito de intertextualidade, desenvolvido e propagado por Julia Kristeva a partir de sua leitura particular dos principais escritos de Mikhail Bakhtin sobre o dialogismo. Fugindo das "idéias de logocentrismo, de ser estável, de substância imutável, de causalidade e de continuidade" (NITRINI, 1997, p. 159), aspectos presentes em boa parcela dos estudos literários, Bakhtin propõe uma lógica correlacional para escapar da prisão do discurso monológico. Distante da crença no domínio absoluto, divino, do autor sobre a linguagem, o teórico russo evidencia que "o escritor nunca encontra palavras neutras, puras, mas somente 'palavras ocupadas', 'palavras habitadas por outras vozes'" (PERRONE-MOISÉS, 1978 , p. 60), sendo a ambivalência uma característica típica da linguagem. Ao conceber a 
literatura como uma infinita rede de textos, uma labiríntica biblioteca infindável ${ }^{11}$, substituindo a noção de intersubjetividade pela de intertextualidade, a questão da intenção pessoal do criador $B$ em dialogar com o criador A passa ao segundo ou terceiro plano, já ressoando - a adaptação de Bakhtin promovida pela semanálise de Kristeva - teorias psicanalíticas em voga naquele momento histórico, especialmente as de Jacques Lacan, nas quais o sujeito é concebido como um ser criado pela e na linguagem, falado pelo outro, e não uma entidade substancial que se utiliza da linguagem para expressar suas vontades.

Contudo, esse diálogo - retomando a tendência sociológica da visão original de Bakhtin que o diferenciou dos seus confrades formalistas russos - não se dá num plano abstrato. A teia textual é parte integrante de discursos sociais em constante entrelaçamento e a atividade literária ocupa um espaço específico dentro da sociedade que é preciso considerar ao se pensar a dinâmica das trocas culturais. Um enunciado nunca está isolado, sua existência - independente de trazer marcas ou não de relação intertextual explícita ou implícita -, segundo Foucault, já é, por si só, a reatualização de outros enunciados. Para a compreensão de um enunciado é necessário perceber seu "campo enunciativo" (FOUCAULT, 1970, p. 164), as condições de enunciabilidade, sua materialidade, "es preciso que un enunciado tenga una sustancia, un soporte, un lugar y una fecha" (FOUCAULT, 1970, p. 169). Sem conceber o enunciado como mero subproduto de um contexto, como afirma o pensamento marxista vulgar ao estabelecer que a infraestrutura econômica determina as manifestações culturais da superestrutura, mas sem igualmente ter uma visão transcendental, idealista ou desumanizada da relação entre textos, Foucault aponta que "el régimen de materialidad al que obedecen necesariamente los enunciados es, pues, del orden de la institución más que de la localización espacio-temporal" (FOUCAULT, 1970, p. 173), sendo que por instituição concebe um sistema de coerção específico - típico de uma função, de um grupo social, de um domínio de saber -, um conjunto de regras e condições de possibilidade que condiciona a produção de determinado enunciado.

Toda enunciação segue determinadas práticas discursivas e, para além da simples vontade do autor ou de um etéreo cruzamento de palavras, tais práticas motivam boa parte dos diálogos encontrados nos mais distintos textos. Para perceber a real dimensão das obras literárias e seus mecanismos correlacionais é necessário situá-las em contextos sociais vivos, concebendo-os materialmente, historicamente, inclusive ressaltando que "as relações sociais são condicionadas pelas relações de produção" (BENJAMIN, 1994, p. 122). Como Pierre Bourdieu demonstra em As regras da arte é essencial perceber como se constitui e quais as leis que regem o campo literário - nunca absolutamente desligado dos demais campos existentes numa sociedade, por mais que um de seus elementos formativos tenha sido o desejo de sê-lo - para analisar as opções estéticas (inclusive os diálogos estabelecidos com outras literaturas, outros autores) dos artistas ao criarem suas obras, às vezes, opções inconscientes, não racionalmente motivadas. Ao refletir sobre como o "industrialismo penetrou na própria literatura" (BOURDIEU, 1996, p. 70), e ressaltar que tal elemento aparentemente "externo" ao texto literário esteve no cerne da construção do conceito de estética pura, do famoso slogan "arte pela arte" no século XIX, Bourdieu fornece luzes novas ao que podia ser lido como idiossincrasia de um grupo de autores ou apenas um efeito de

\footnotetext{
${ }^{11}$ Clássica imagem formulada no conto "Biblioteca de Babel", de Jorge Luís Borges, um dos autores mais atentos à conjunção leitura-escritura: "Borges présent au contraire son écriture comme une lecture, déguise en lecture son écriture. Ces deux conduites, faut-il le dire, sont complémentaires, elles s'unissent en une métaphore des relations, complexes et ambiguës, de l'écriture et de la lecture: relations qui sont bien evidemment - j'y reviendrai s'il le faut - l'âme même de l'activité hypertextuelle." (GENETTE, 1982, p. 296).
} 
um abstrato espírito do tempo ou um passo natural da evolução das formas, como se essas fossem formas de vida independentes do universo que as rodeiam.

O estudo de uma relação intertextual como a dos romances de Carlos Heitor Cony com o existencialismo sartriano, pressupõe diversos planos de interação cultural, social, institucional, política etc., que vão muito além do simples contato entre um criador $B$ com um criador A. No mínimo, pode remeter a todo um longo histórico de trocas - o termo é exagerado, afinal, na maioria das vezes, a via foi unidirecional - intelectuais entre Brasil e França, no qual questões como atraso, dependência, submissão (de um lado) e autoridade, domínio econômico e cultural, exploração do capital simbólico (do outro lado) entram em jogo, assim como também exercem importante papel as estratégias diversas utilizadas para inverter ou redefinir tais condicionamentos, os modos particulares de assimilação, adaptação ou até inversão e rejeição desses elementos "alienígenas" ao ingressarem no habitat do receptor, algo que, por sua vez, exige voltar a atenção para as particularidades da vida nacional em seus diversos planos (social, ideológico, religioso, político, econômico, cultural) que orientam a leitura, às vezes, enviesada do "outro".

Outro aspecto que exigiria uma abordagem mais abrangente da relação entre leitura e escritura do que a recorrente é acompanhá-la para além da obra produzida, verificá-la no próprio fazer literário, independentemente de traços desse diálogo manterem-se explicitamente incrustados no corpo do texto resultante. Menos do que uma opção secundária de remeter a outros textos como forma de produzir um ornato estético, como prova de erudição ou busca de apoio na auctoritas de um objeto artístico consagrado pela tradição, a relação pode ser vista como um fator essencial à comunicação em todas suas etapas, inclusive na comunicação escrita, sempre vista como menos interativa do que a oral. Para Roman Ingarden e Wolfgang Iser, "a obra escrita é um esboço para a leitura" (RICCEUR, 1994, p. 118) e essa, longe de ser apenas a ilha de passividade imaginada por alguns, já é uma atividade criativa por si só ao exigir o preenchimento dos "pontos de indeterminação próprios ao estrato dos objetos apresentados" (ZILBERMAN, 1989, p. 14), de acordo com as possibilidades particulares do horizonte de expectativa do público leitor de cada época, local e da formação sociocultural de cada indivíduo. Além disso, pode também ser o primeiro momento de atos de produção escrita futuros - nem que tão somente no plano das reflexões prévias a qualquer ato concreto de criação, no despertar de idéias, na abertura de possibilidades, no aguçar de interesses a serem desenvolvidos ou não. Um texto, como comenta Louis Hay, é um "objet à deux faces: inclus à la fois dans un processus de genèse dont il est le terme, et dans un processus de lecture dont il est l'origine" (HAY, 1994, p. 18) ${ }^{12}$.

Relativizando as noções de termo e origem utilizadas pelo crítico genético francês, é necessário ter em mente que há uma circularidade no sistema literário que perpassa todos seus momentos e motiva uma constante troca de papéis entre leitores e escritores. $O$ autor é antes de tudo um leitor, inclusive ao produzir sua própria obra: "La phase d'écriture est précédée par la relecture du travail précédent" (LÉBRAVE, 1986, p. 135). É possível questionar a capacidade do produtor ter a mesma posição de exterioridade diante do objeto produzido por ele que um terceiro pode ter, como aponta Sartre. Contudo, ainda assim, o escritor sempre é seu primeiro leitor. Em sua "autoleitura" (que pode ser concomitante ao

\footnotetext{
${ }^{12}$ Nesse trecho o crítico genético francês reflete sobre a sintonia entre as possibilidades sucessivas da escritura e os efeitos diversos da leitura, como fica claro na citação de Paul Valéry que utiliza logo a seguir: "Cette diversité possible des effets légitimes d'une œuvre est la marque même des œuvres de l'esprit. Elle correspond, d'ailleurs, à la pluralité des voies qui se sont offertes à l'auteur pendant son travail de production" (VALÉRY apud HAY, 1994, p. 18).
} 
ato de escrita, não uma atividade posterior) entra em pauta não apenas a verificação do quanto o objeto em criação está adequado ou não aos seus objetivos, mas também a presença virtual de todos leitores numa idéia geral sobre suas expectativas, as quais não deixam de ter peso no desenvolvimento da escrita ao serem aceitas, adaptadas ou confrontadas, enfim "I'horizon d'attente' des lecteurs que l'écrivain prend en compte pour écrire" (JAUSS, 1989, p. 167). Além disso, todo leitor é um potencial criador, no ato de recepção já há o germe do advento da "resposta" - nem sempre direta, muitas vezes que não traz em sua fatura nenhum elemento que remeta à pergunta. A leitura, especialmente a de obras ficcionais ou poéticas, que por sua ambiguidade latente exigem o engajamento da imaginação em doses cavalares para a construção do sentido, não é um simples processo de decodificação. A estrutura de apelo do texto, como a denomina Wolfgang Iser, envolve todo o sujeito, exige sua participação, sua entrega, sua modificação ${ }^{13}$. A obra lida não é um monólito, uma verdade perfeita e fechada que se encerra em si, pelo contrário, é algo aberto, cheio de vazios, cheio de sentidos que ultrapassam em muito as próprias intenções enunciativas de seu produtor. Ela espera e pressupõe um diálogo que a leve além, pede para ser retomada, não para repetir-se, mas para criar novas obras, novos enunciados que darão prosseguimento à conversa ${ }^{14}$ : "Toda obra [verdadera?] abre un horizonte de búsquedas, esto quiere decir que hace posible algo que no lo era antes de ella" (MERLEAU-PONTY, 1971, p. 129).

Tais aspectos da criação artística em geral somam-se à particularidade da criação através da linguagem escrita, pois a literatura é a arte do devir, só existe em ação (escrever ou ler). Diferentemente de um quadro, a obra literária é um objeto que só existe a partir de uma recepção ativa, de uma construção mental de um outro. O objeto literário é "dado através da linguagem, nunca é dado na linguagem" (SARTRE, 1989, p. 37) ${ }^{15}$. Exige o engajamento do sujeito da leitura, pois esta é uma forma de criação a partir de pautas dadas pelo objeto: "a leitura é uma criação dirigida" (SARTRE, 1989, p. 38). Sartre compreende a obra literária como uma composição em conjunto em que as liberdades do autor e do leitor se completam. $\mathrm{O}$ escritor se projeta na obra, procura a si mesmo e encontra a si mesmo no desvendamento do ato criativo. Ele, por isso mesmo, está condenado a não enxergar o "produto" em sua objetividade, desligado de si. Para tanto necessita da, como poeticamente

\footnotetext{
${ }^{13}$ Para Iser, a grande função da literatura é estimular mutações no leitor durante sua busca por tentar suprir os vazios do texto. O valor da literatura reside mais na experiência proporcionada por esse embate entre as expectativas prévias e as dificuldades apresentadas pela obra, a superação necessária para dar vida e sentido ao texto, do que no objeto artístico em si: "a relação entre texto e leitor só pode ter êxito mediante a mudança do leitor" (ISER, Wolfgang, 1979, p. 88). Como afirma Merleau-Ponty, filósofo com pensamento inegavelmente próximo ao de Iser, talvez por beberem na fonte comum da fenomenologia, "o Ser é o que exige de nós criação para que dele tenhamos experiência" (CHAUÍ, 2008, p. 46).

14 "O advento, porém, é o excesso da obra sobre as intenções significadoras do artista; é aquilo que sem o artista ou sem o pensador não poderia existir, mas é também o que eles deixam como ainda não realizado, algo excessivo contido no interior de suas obras e experimentado como falta pelos que virão depois deles e que retomarão o feito através do não-feito, descobrindo o por-fazer solicitado pela obra. $O$ advento é aquilo que, do interior da obra, clama por uma posteridade, pede para ser acolhido, exige uma retomada porque o que foi deixado como herança torna-se doação, o dom para ir além dela." (CHAUÍ, 2008, p. 52-53). Interessante notar que tal lógica pergunta-resposta é utilizada, em outra perspectiva, por Jauss, retomando reflexões de Collingwood: "só se pode entender um texto quando se compreendeu a pergunta para a qual ele constituiu uma resposta" (COLLINGWOOD apud JAUSS, 1994, p. 37).

${ }^{15}$ Uma leitura mais detalhada sobre a(s) concepção(ões) do fazer literário em Sartre foi publicada na revista Manuscrítica, número 13 (Vide bibliografia).
} 
denomina, generosa criação propiciada pela liberdade do outro, do leitor. A obra constituise de um pacto de confiança entre leitor e autor, ambos, com o engajamento criativo de suas liberdades, passam a participar de algo que ultrapassa suas subjetividades, passam a integrar a totalidade de uma obra resultante dessa relação. Sartre sintetiza esta fórmula ao comentar que "a alegria estética provém da consciência que tomo de resgatar e interiorizar isto que é o não-eu por excelência" (SARTRE, 1989, p. 49) ${ }^{16}$. Enfim, escrever para Sartre é "desvendar o mundo e propô-lo como uma tarefa à generosidade do leitor. Recorrer à consciência de outrem para se fazer reconhecer como essencial à totalidade do ser" (SARTRE, 1989, p. 49).

Essa concepção da atividade literária como uma troca, um ato de comunicação, foi para época em que o ensaio de Sartre foi publicado, algo relativamente novo. Apenas no final da década de 1960, os estudos literários, especialmente os desenvolvidos pelo grupo da Escola de Konstanz, pensadores influenciados pela hermenêutica de Hans Georg Gadamer e pelas reflexões sobre a natureza sígnica da obra de arte de Jan Mukarovsky, passam a reintegrar o leitor em suas análises destacando seu papel ativo na produção de sentidos para a obra. Uns dos principais teóricos da Estética da Recepção, Hans Robert Jauss ao comentar a relação entre criação e recepção em "Réception et production: le mythe des frères ennemis" retoma o pensamento sartriano sobre a complementaridade entre o aspecto produtivo e receptivo da atividade literária, ao notar a importância do outro para concretizar a autonomia da obra como objeto: "Si l'on écrivait uniquement pour soi-même, l'cevre ne verrai jamais le jour en tant qu'objet" (JAUSS, 1989, p. 166). Só o receptor pode efetuar a concretização da obra, como aponta em suas reflexões também Wolfgang Iser, retomando conceito de Roman Ingarden. Sartre antecipa questões que correntes dos estudos literários distintas, mas complementares, como a crítica genética e a estética da recepção, irão se desenvolver a partir de outras referências teóricas, analisando como esses pólos do sistema literário influenciam-se mutuamente na construção do(s) sentido(s) da obra literária. Além da importância para a doação de sentido para cada objeto estético particular, tal diálogo é propiciador do eterno ciclo de criação de outras obras. Perceber o autor enquanto leitor, que a leitura não é o pólo oposto da criação, pelo contrário, é "uma etapa das relações interliterárias genéticas" (CARVALHAL, 1992, p. 71) é uma das saídas para tornar mais dinâmicos e pertinentes os estudos comparativistas. Como aponta Yves Chevrel, "la permutation de rôles de $X$ et de $Y$ est la reconnaissance du fait que le récepteur est pris comme point de départ et non comme plus point d'arrivée: recevoir est une activité." (CHEVREL, 1989, p. 180).

Essa simbiose da recepção com a produção é ainda pouco explorada nos estudos das práticas de criação literária, no entanto, principalmente os pesquisadores da crítica genética brasileira - menos presos ao fetiche do manuscrito raro (com todas suas implicações institucionais e mercadológicas) e ao afã de cientificidade marcantes no campo intelectual francês, onde surgiu tal corrente dos estudos literários dedicada aos bastidores da atividade literária - já demonstraram sensibilidade para compreender que o ato criador não reside apenas em manuscritos relativos ao trabalho de escrita que resultará numa obra determinada. A mente criativa de um artista não para quando está longe de sua

\footnotetext{
${ }^{16}$ Algumas reflexões de M. Bakthin em Estética da Criação Verbal também versam sobre a necessidade da alteridade para a consolidação do objeto estético: "A nossa consciência nunca dirá a si mesma a palavra concludente" (BAKHTIN, 2003, p. 14), "O homem tem uma necessidade estética absoluta do outro" (BAKHTIN, 2003, p. 33), "A vida não pode gerar uma forma esteticamente significativa sem ultrapassar seus próprios limites, sem deixar de ser ela mesma." (BAKHTIN, 2003, p. 64).
}

$$
\sim 76 \sim
$$


escrivaninha, do caderno de rascunhos ou de seu notebook. Pelo contrário, talvez o que vemos nos considerados documentos de processo registre apenas uma pequena parcela do enorme esforço intelectual anterior - ou mesmo paralelo, mas não grafado num texto, rascunho ou nota - ao ato de escrita e que faz parte da atividade artística, inclusive aqueles insights que não são aproveitados, ao menos diretamente, na denominada obra final. A escrita é a ponta do iceberg, essencial, mas não dá mostras de tudo que ocorreu até chegar a ela. Faz falta abrir o campo de visão para enxergar os múltiplos "espaços escriturais", como os denomina Verónica Galíndez Jorge (PINO e ZULAR, 2007, p. 130), que rodeiam o escritor, às vezes aparentemente dissociados de sua produção propriamente dita. Tal tipo de estudo, principalmente nas correntes de orientação mais semiótica, voltadas para a análise da criação nas artes plásticas, já é bastante comum como é visível, por exemplo, na ênfase no papel do ateliê do artista e de sua organização para o entendimento de sua concepção de arte, como abordado nos trabalhos do grupo de pesquisadores da PUC-SP, principalmente os coordenados por Cecília Almeida Salles.

Muitos elementos que não se limitam à vontade do produtor participam do processo de criação. Uma manchete de jornal do dia, uma foto sobre a estante, uma música que toca no apartamento ao lado todo santo dia podem ter implicações consideráveis, apesar de dificilmente mensuráveis, sobre a escrita de determinado autor, em determinado momento. Cony, por exemplo, explica em grande medida seu retorno à escrita ficcional após duas décadas de afastamento recorrendo à influência de dois elementos que fogem muito do que se concebe como motivações essenciais para a atividade literária numa visão idealista, distantes de qualquer noção de inspiração ou necessidade interior de expressão latente. 0 escritor carioca costuma enfatizar que o surgimento do computador em sua vida - com todas as facilidades para a produção de textos trazidas pela máquina, se comparada com sua antepassada, a máquina de escrever - e a necessidade de pajear a agonia de sua querida cadela Mila em longas noites em vigília tiveram enorme importância para o despretensioso começo da escrita de algo que se tornou posteriormente o romance Quase Memória, obra de reestréia do autor, publicada em 1995. Perceber que a criação não se dá ex nihilo, do nada, não depende apenas do fiat lux de um autossuficiente sujeito isolado, é um dos grandes méritos de tais pesquisas.

Um dos espaços escriturais mais destacados para a atividade literária é a leitura. Para um escritor, ler - além da atividade criativa exigida de qualquer leitor, até do menos crítico, do mais interessado apenas na fruição da obra - é um momento de aprendizado, um exercício indireto de escrita, de identificação de estilos, de modos de construção, momento de conscientização de problemas inerentes ao uso da linguagem, de atualização aos procedimentos em voga - mesmo quando não usados ou até repudiados - e, essencialmente, o momento da percepção da diferença. Apenas no confronto com o outro a identidade se delineia; a subjetividade é marcadamente intersubjetiva, exige diálogo e tensão com o semelhante-diferente. A leitura de um escritor também costuma ser eminentemente crítica, como se pode observar nas correspondências trocadas entre alguns grandes nomes da literatura nacional e mundial, aspecto evidente nas correspondências de Mário de Andrade ou Gustave Flaubert. Um sapateiro, como bem o sabe o pintor de famosa anedota que explica o provérbio "não vá o sapateiro além dos sapatos", ao ver um sapato representado ou um sapato real possui um conhecimento técnico sobre o ofício e sobre o produto dessa atividade muito maior do que o de um simples usuário. Pode, por exemplo, saber que um sapato é bonito, mas não irá durar muito tempo por causa do material 
utilizado ou do modo como foi feito, algo que o consumidor comum simplesmente desconhece.

Além de crítica, a leitura de um especialista em escrever pode ser autocrítica e criativa: autocrítica porque diante dos problemas e soluções encontrados na recepção da obra de outro, um escritor pode reavaliar seus procedimentos técnicos, sua visão de mundo, o próprio modo de conceber sua arte e criativa porque o espaço de leitura, franqueado ao imaginário, é terreno fértil para que na já normalmente motivada mente de um escritor brotem idéias, temas, personagens, versos, sonoridades, cenas, léxicos, tons, modalidades de voz narrativa etc. Ressalve-se que tal processo criativo não se reduz à cópia ipsis litteris de algum aspecto da obra que está sendo lida. Telê Ancona Lopez, especialista no estudo dos arquivos de Mário de Andrade, ao dedicar-se à sua rica marginália - comentários escritos pelo autor paulistano nas margens dos livros de sua biblioteca - aponta como o criador de Macunaíma ao ler Les Fleurs du Mal, de Charles Baudelaire (leitura registrada pelo comentário grafado no corpo da obra alheia, nas páginas do livro) empreende um processo de "captação e transmutação" (LOPEZ, 2002, p. 65) que desemboca em versos de sua Paulicéia Desvairada.

Tal mergulho nas leituras - e nos modos como elas se dão - de um escritor em consonância com sua atividade criativa abre maiores perspectivas para se pensar a intertextualidade:

a análise de cunho genético das obras pode ultrapassar a crítica de influências, a constatação das fontes, ao se empenhar na recuperação de sinais da eclosão ou na verificação de amálgamas operadas pelo ato criador, tangíveis na biblioteca, isto é, nas leituras de um escritor, de um filósofo, de um cientista, de um artista plástico ou de um cineasta. (LOPEZ, 2002, p. 46)

Sem a ênfase em encontrar registro comprovado por meio de rasuras, marcações, comentários ou pela simples presença do objeto livro na biblioteca pessoal de um escritor ${ }^{17}$, a pesquisa desenvolvida em torno da relação do processo de composição de $O$ Ventre, de Cony, com as obras existencialistas, especialmente os romances sartrianos, se relaciona com essa preocupação de entender a criação como diálogo, um circuito de pergunta-resposta inesgotável - sem noção de dependência, sem hierarquização, resguardando a liberdade de cada qual aderir, negar, subverter, alterar, modificar o outro em si, tudo isso sem necessariamente ter que citá-lo. Como sugere Pierre-Marc de Biasi: "Je pense par exemple à l'immense domaine de l'intertextualité dont la plus grand part agit dans le texte en restant irrepérable" (BIASI, 1998, p. 60). De certo modo, o estudo das reescritas de O Ventre, tentando ver na transição entre as versões, mais do que no texto específico de uma delas como no exemplo citado na primeira parte deste artigo, a presença do intertexto existencial, segue orientação semelhante. Ainda há que se fazer a história das grandes tertúlias travadas entre literatos ocultas pelo silêncio dos textos publicados, das leituras essenciais, daquelas que podem até não ter deixado marcas visíveis nas obras do escritor-leitor, mas consolidaram - nem que seja por repulsa, oposição - seu modo de encarar a prática literária ou mesmo foram fundamentais para a construção de sua concepção de mundo. $\mathbf{c}^{\mathbf{J}}$

\footnotetext{
${ }^{17}$ Alguns dos livros mais marcantes lidos por um escritor, às vezes, nem eram seus, principalmente aqueles lidos durante a infância e/ou adolescência.
} 


\section{REFERÊNCIAS BIBLIOGRÁFICAS}

BAKHTIN, Mikhail. Estética da Criação Verbal. Trad. Paulo Bezerra. 4a ed. São Paulo: Martins Fontes, 2003.

BENJAMIN, Walter. "O autor como produtor. Conferência pronunciada no Instituto para o Estudo do Fascismo, em 27 de abril de 1934". In. BENJAMIN, Walter. Magia e técnica, arte e política: ensaios sobre literatura e história da cultura. Trad. Sérgio Paulo Rouanet. 7. ed. São Paulo: Brasiliense, 1994.

BIASI, Pierre-Marc. "Qu'est-ce qu'un brouillon?" In. CONTAT, Michel \& FERRER, Daniel (orgs.). Porquoi la critique génétique?. Paris: CNRS Edition, 1998.

BLOOM, Harold. A angústia da influência - uma teoria da poesia. Rio de Janeiro: Imago, 1991.

BOURDIEU, Pierre. As Regras da Arte. Gênese e estrutura do campo literário. São Paulo: Companhia das Letras, 1996.

BUENO, Raquel Illescas. Os Invólucros da Memória na Ficção de Carlos Heitor Cony. São Paulo: USP, 2002.

CARVALHAL, Tania Franco. Literatura Comparada. São Paulo: Ática, 1992.

CHAUÍ, Marilena. "Merleau-Ponty: a obra fecunda". In. Cult n.o 123, São Paulo, abril de 2008.

CHEVREL, Yves. "Les études de réception". In. BRUNEL, Pierre \& CHEVREL, Yves. Précis de littérature comparée. Paris: PUF, 1989.

COMPAGNON, Antoine. La second main ou le travail de la citation. Paris: Éditions du Seuil, 1979.

CONY, Carlos Heitor. O Ventre. 8a ed. São Paulo: Companhia das Letras, 1998.

. O Ventre. Datiloscrito inédito, 1955.

FOUCAULT, Michel. La Arqueologia del saber. México: Siglo XXI Editores S.A., 1970.

GENETTE, Gérard. Palimpsestes. La littérature au second degré. Paris: Éditions du Seuil, 1982.

HAY, Louis. "Critiques de la critique génétique". Genesis n.ำ6, Paris, 1994.

HUTCHEON, Linda. Poéticas do Pós-Modernismo. Rio de Janeiro: Imago, 1991. 
ISER, Wolfgang. "A interação do texto com o leitor". In. LIMA, Luiz Costa. A Literatura e o Leitor. Textos de Estética da Recepção. Rio de Janeiro: Paz e Terra, 1979.

JAUSS, Hans Robert. A História da Literatura como provocação à Teoria Literária. São Paulo: Ática, 1994.

JAUSS, Hans Robert. "Réception et production: le mythe des frères ennemis". In. HAY, Louis (org.). La Naissance du texte. Paris: José Corti, 1989.

JENNY, Laurent. "A estratégia da forma". In. Intertextualidades. Coimbra: Almedina, n. 27, 1979, p. 5.

LÉBRAVE, Jean-Louis. "L'écriture interrompue: quelques problèmes théoriques". In. HAY, Louis (org.). Le manuscrit inachevé. Écriture, création, communication. Paris: CNRS Éditions, 1986.

LOPEZ, Telê Ancona. "A biblioteca de Mário de Andrade: Seara e celeiro da criação". In. ZULAR, Roberto (org.). Criação em Processo - Ensaios de Crítica Genética. São Paulo: Editora Iluminuras, 2002.

MERLEAU-PONTY, Maurice. La prosa del mundo. Madrid: Taurus, 1971.

MILLER, J. Hillis. "O Crítico como Hospedeiro" In. A ética da leitura: ensaios 1979-1989. Rio de Janeiro: Imago Ed., 1995.

NITRINI, Sandra. Literatura Comparada. História, Teoria e Crítica. São Paulo: Edusp, 1997.

NUNES, Benedito. "A náusea". In. O Dorso do Tigre. Ensaios. São Paulo: Perspectiva, 1969.

PERRONE-MOISÉS, Leyla. Texto, Crítica, Escritura. São Paulo: Ática, 1978.

PINO, Claudia Amigo \& ZULAR, Roberto. Escrever sobre escrever: uma introdução crítica à crítica genética. São Paulo: WMF Martins Fontes, 2007.

RICCEUR. Paul. Tempo e Narrativa (tomo 1). Trad. Contança Marcondes Cesar. Campinas, SP: Papirus, 1994.

SANTOS, Kleber Pereira. "A visão existencialista da criação literária". In.: Manuscrítica no 13. São Paulo, janeiro de 2005.

São Paulo: USP, 2009.

. Da Paixão Inútil: O existencialismo na escrita de Carlos Heitor Cony.

SARTRE, Jean-Paul. A Idade da Razão. Trad. Sérgio Milliet. São Paulo: Abril Cultural, 1981.

. L'âge de raison. Paris: Gallimard, 1945.

. La nausée. Paris: Gallimard, 1938. 
. Que é literatura?. São Paulo: Ática, 1989.

SILVA, Franklin Leopoldo e. Ética e literatura em Sartre: ensaios introdutórios. São Paulo: Editora Unesp, 2004.

ZILBERMAN, Regina. Estética da Recepção e História da Literatura. São Paulo: Ática, 1989.

Artigo recebido em: 31/07/09

Artigo aprovado em: 03/09/09

Referência eletrônica: SANTOS, Kleber P. "O Dissecador de Passarinhos e a Idade da Razão Reflexões sobre a relação entre recepção e criação na produção literária", Revista Criação \& Crítica (online), n. 3, p.65-81, 2009. 